\title{
Princess of palaeontology
}

Mary Anning came from humble origins to find fame as a fossil hunter on England's south coast. Others took credit for her discoveries but it was said of her that she understood more of the science than "anyone else in the kingdom".

\section{Crispin Tickell}

T his year is the bicentenary of the birth of Mary Anning of Lyme Regis. She has become famous first as the discoverer — and saleswoman — of the exotic fossil creatures of the Lower Jurassic; and secondly as the prettified heroine of many children's books, sometimes identified with she "who sells sea-shells on the sea shore". A recent symposium in her honour at Lyme Regis brought together palaeontologists, historians and sociologists of science.

Anning was the daughter of a carpenter or cabinet-maker. Although she wrote that she was illiterate, this was far from so. Her letters were clearly written, and she is said to have taught herself French in order to read Georges Cuvier. Her father collected and sold 'curiosities' from the Dorset cliffs and beaches, and when he died in 1810 heleft her, his son Joseph and his widow Molly the rudiments of a business. It seems to have been Joseph who uncovered the head of the famous ichthyosaur, which he and Mary excavated and sold.

It requires a major effort of the imagination to think back into the mental world of the 1820s. How did she interpret the world around her, and the place in it of the fossils she found? At one level far from hers, the concept of deep time was just beginning to take hold. In 1795 James Hutton set out the notion of a past and present in which "we find no vestige of a beginning, no prospect of an end". But for most people, including those in rural Dorset, the Bible derived directly from God and was the overriding authority on the history of the Earth (notoriously begun, according to Archbishop Ussher, at 9 a.m. on 26 October 4004 BC). Fossil creatures deep in the cliffs with no apparent living descendants presented an obvious difficulty. It was suggested that they had been entombed by the Flood, or even left around by God as a test of people's faith.

The span of Anning's life, from 1799 to 1847 , was an age when geology was seen as the queen of the sciences. Anning herself was described as "the princess of palaeontology" in 1837. After despairing efforts to link the fossil evidence with biblical chronology, most geologists gave up, and the more pious were content to interpret the Bible as metaphor. On one side were the uniformitarians of the school of Hutton, William Smith and Charles Lyell; and on the other the catastrophists, often with a theological agenda, who saw history as a series of relatively sudden events or interventions. By the time Anning died, the uniformitarians were in the ascendancy.

Most of the leading geologists of the day-

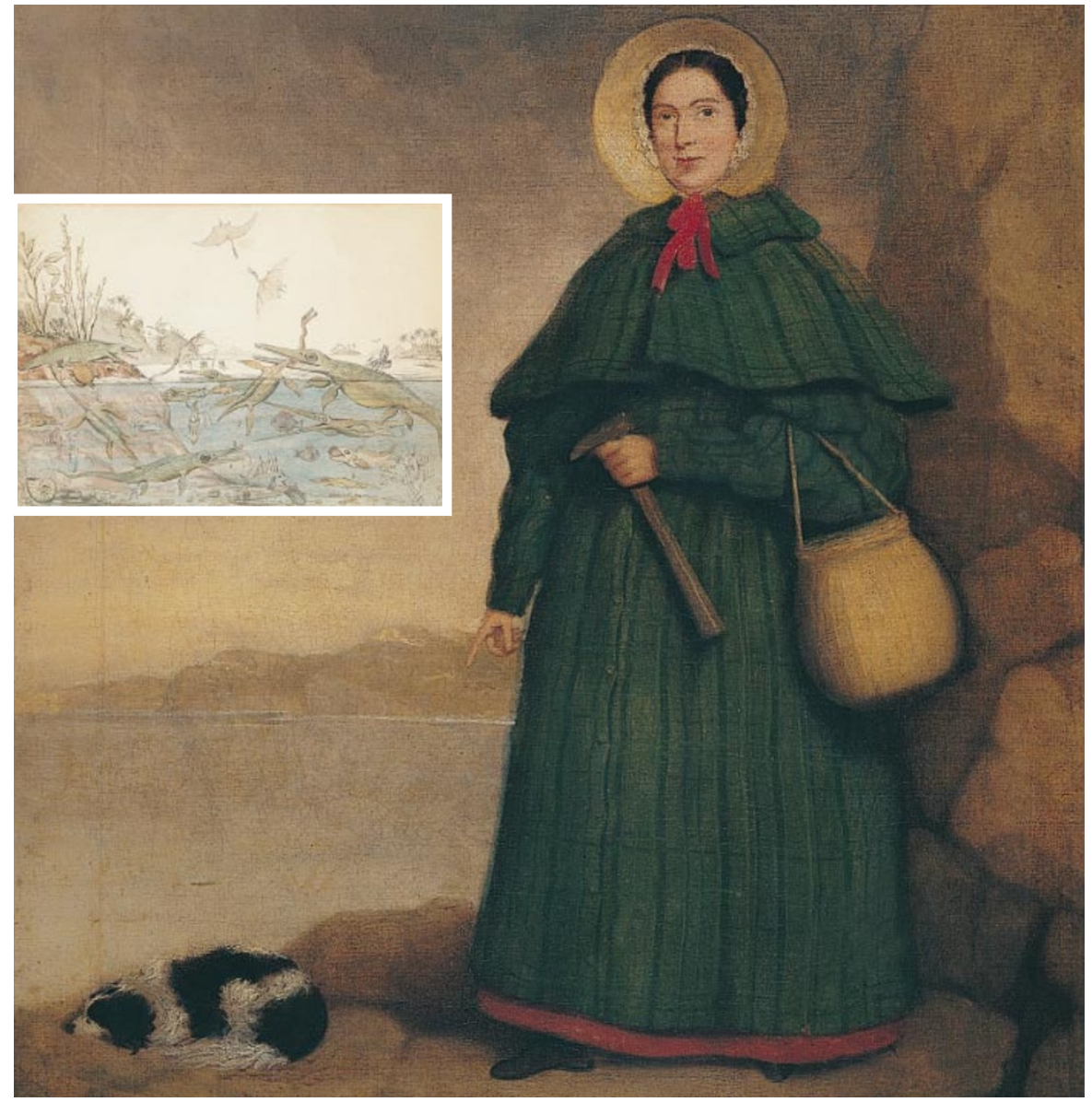

Anning: her talent for finding and evaluating fossils won her tributes from eminent geologists of the day.

William Buckland, Henry De La Beche, Roderick Murchison, Adam Sedgwick, Louis Agassiz and others - visited Lyme Regis, and knew Anning. Some came as customers for her fossils, and made expeditions with her. She must have been aware of current controversies and, as Lady Silvester wrote in 1824, "she has arrived at that degree of knowledge as to be in the habit of writing and talking with professors and other clever men... and they all acknowledge that she understands more of the science than anyone else in the kingdom".

She certainly recognized the enormous antiquity of the fossils, and doubted whether they had living counterparts. Theory she left to others. Cautious scepticism was one of her abiding characteristics.

Her strength was practical. She had an extraordinary talent for finding, assembling and evaluating fossils. The list is impressive: four ichthyosaurs, two plesiosaurs, a pterodactyl, the fossil fish Squaloraja, plus ammonites, sea urchins and other marine fossils. It was she who recognized coprolites as fossil faeces, and who, by comparing existing sea hares with fossil belemnites, worked out the association of the belemnite with its ink bag. By grinding up the sepia from a fossilized belemnite ink bag, she made ink for her friends to use in sketching fossils.

Anning suffered from every social handicap. She was poor for all but her last few years, when friends secured a modest pension for her. As a woman she had no prospect of professional recognition. Almost all her discoveries bear the names of those who bought specimens from her. As late as 1930 a local historian described her as no more than a "handmaid of scientific men".

But that was not the view of the scientific men. On her death De La Beche read out an unprecedented tribute to her at the Geological Society. No wonder that she has become something of an icon. Looking at the traces sheleft, she emerges as a tough, independentminded person of skill and intelligence who surmounted her circumstances to help lay the foundations for a new science of the Earth. $\square$ Crispin Tickell is at Ablington Old Barn, Ablington, Cirencester, Gloucestershire GL7 5NU, UK. 